\title{
Effectiveness of Structured Teaching Programme on Knowledge Regarding Antenatal Care among Pregnant Women
}

\author{
Pinal Bhabhor ${ }^{1}$, Sijo Koshy ${ }^{2}$ \\ M.Sc. Nursing student, Sumandeep Nursing College, Sumandeep Vidyapeeth, Piparia, Vadodara-391760, Gujarat, India \\ Guide, Associate Professor, Obstetrics \& Gynaecological Nursing, Sumandeep Vidyapeeth- Sumandeep Nursing College, Vadodara, \\ Gujarat, India
}

\begin{abstract}
Background: The antenatal care is complete when health information is imparted. About 60-80\% of neonatal death is attributed to low birth weight, and low birth weight is highly associated with maternal nutrition. In $20 \%$ of low birth weight is due to maternal malnutrition. The study was to determine the effectiveness of structured teaching programme on knowledge regarding antenatal care. Aims and objectives: The aim of the study is to assess the level of knowledge on antenatal care among pregnant women of selected rural area of vadodara. Material and method: Pre experimental one group pre-test - post-test research design, and non probability convenience sampling technique was adopted to achieve the goal of the study. The tool consists of two parts. First part consist demographic data of the sample and second part consist of structured knowledge questionnaires. The sample was 60 pregnant women taken from rural area of Vadodara. Results: The collected data was tabulated and analysed using descriptive and inferential statistics. In the pre-test mean score was $14.22+4.041$ and post-test means score was $22.24 \pm 4.769$. The post-test level of knowledge mean score is significantly graters than the pre-test knowledge mean score. The ' $t$ ' calculated value 9.082 is more than tabulated value 2.56 (Significant at 5\% level). Conclusion: The ' $t$ ' test was computed between pre-test and post-test score indicate that there was improvement the level of knowledge among pregnant women. Hence it incanted that structured teaching programme was effective. Therefore $\mathrm{H}_{1}$ was accepted. and (RH2) is partially accepted.
\end{abstract}

Keywords: Knowledge, Effectiveness, structured teaching programme, pregnant women

\section{Introduction}

Antenatal care means "care before birth". Antenatal care aims to monitor and promote the well being of a mother and her developing baby. Specific exercise and posters can help the pregnant women to adopt the physical changes in her body during the childbearing year. Antenatal diet also help to Antenatal mother to improving nutritional status of mother and fetus. They will help to ease the minor aches and pain during pregnancy and may also help to prevent longerterm post partum problems. In addition, coping skills such as relaxation, positioning and breathing awareness will provide the mother and her partner with the practical means of managing labour. The main aim of antenatal care is to maintain with physiology of pregnancy and to prevent or to detect at the earliest and to treat and untoward complication that may arise. The promotion of health and maintenance of healthy lifestyles have become objectives of utmost importance to health care profession.

\section{Need for the Study}

Reproductive Health and Research at WHO conducted a multicentre cluster-randomized controlled trial to evaluate routine antenatal care in developing countries. A total of 53 antenatal care clinics in Argentina, Cuba, Saudi Arabia and Thailand were randomly assigned to provide either the new WHO model of care or the standard model used in that country. Altogether, 27 clinics were assigned to use the new model and 26 clinics to use the standard model. In total, 24 678 women were enrolled over an 18 -month period between 2010 and 2012. Women attending the clinics that had been randomly assigned to use the new model had a median of five visits; those visiting clinics providing standard care had a median of eight visits. Fetal growth and birth weight is influenced by a variety of factors, racial, social and economic among others, as well as specific medical conditions that may be present or that may develop during pregnancy.

\section{Objectives}

- To assess the existing knowledge regarding antenatal care among pregnant women.

- To assess the effectiveness of structured teaching programme on knowledge regarding antenatal care among pregnant women.

- To assess the association between pretest score knowledge with the select demographic variables to identify the effectiveness of structured teaching programme.

\section{Hypothesis}

H1: The mean post test knowledge score of structured teaching programme will be significantly higher than the mean pre test knowledge scores.

H2: There will be significant association between pre test knowledge score and selected demographic variables.

\section{Conceptual Framework of the Study}

King`s theory of goal attainment and conceptual framework has been applied in many different situations. Literature 


\section{International Journal of Science and Research (IJSR) \\ ISSN (Online): 2319-7064}

Index Copernicus Value (2013): 6.14 | Impact Factor (2015): 6.391

documents its application across various age groups, from infants through children and adults to the elderly. It has been applied in various health care settings such as hospitals, clinics, and nursing homes.

\section{Research Methodology}

\subsection{Research approach}

Evaluatory approach

\subsection{Research design}

One group pre test, post test design.

\subsection{Variables}

6.3.1 Independent variables: Structure teaching programme on antennal care.

6.3.2 Dependent variable: Knowledge of pregnant women

\subsection{Criteria for selection of sample}

\subsubsection{Inclusion criteria}

- Pregnant women in that all are including prime, multi gravida,.

- Pregnant women who can understand Guajarati, Hindi, English language.

- Pregnant women who are willing to take part in the study.

- Pregnant women who are available at the time of data collection.

\subsubsection{Exclusion criteria}

- Pregnant women with previous history of high risk pregnancy.

- Pregnant women who have attended previous studies.

- Pregnant women who are not willing to take part in the study.

\subsection{Sample}

Pregnant women from rural area of Vadodara district.

\subsection{Sampling Technique}

Non-Probability Convenience Sampling Technique

\subsection{Sample size}

60 pregnant women

\subsection{Development of Tools}

The tool consisted as below section:

Tool-1- Demographic Questionnaire:- A six item were used to collect the sample characteristics includes, Age. Education, occupation, religion, monthly income, type of family.

Tool-2- 25 Self Structured knowledge questionnaire on antenatal care.

\section{Result}

The data was analyzed and presented in the following sections:

The data collected were edited, tabulated, analyzed, interpreted and finding were presented in form of tables and diagrams represent under the following areas.

Section I: Description of demographic variables of the pregnant women.

Section II: Assessment of knowledge score on pre test and post test after administration of structured teaching programme.

Section III: Effectiveness of Structured teaching programme on knowledge regarding antenatal care among pregnant women.

Section IV: Association of pre-test knowledge regarding antenatal care among pregnant women with selected demographic variables.

Section - I Demographic variables of pregnant women

Table 1: Frequency and percentage distribution of pregnant women by their characteristics such as age, education, occupation, religion, type of family, monthly family income.

\begin{tabular}{|c|c|c|c|}
\hline & $n=c$ & & \\
\hline Sr.no. & Variables & Frequency & Percentage \\
\hline 1 & $\begin{array}{l}\text { Age of mother ( in years): } \\
\text { a. } 18-23 \\
\text { b. } 23-28 \\
\text { c. } 28-33 \\
\text { d. } 33-38\end{array}$ & $\begin{array}{l}10 \\
32 \\
12 \\
06\end{array}$ & $\begin{array}{l}20 \% \\
53 \% \\
17 \% \\
10 \%\end{array}$ \\
\hline 2. & $\begin{array}{l}\text { Education status of } \\
\text { mother: } \\
\text { a. Primary school } \\
\text { b. Middle school } \\
\text { c. High school } \\
\text { d. Illiterate }\end{array}$ & $\begin{array}{l}20 \\
12 \\
11 \\
17\end{array}$ & $\begin{array}{l}34 \% \\
20 \% \\
18 \% \\
28 \%\end{array}$ \\
\hline 3. & $\begin{array}{l}\text { Occupation of mother: } \\
\text { a. house hold worker } \\
\text { b. Health care worker } \\
\text { c. House wife } \\
\text { d. Others }\end{array}$ & $\begin{array}{l}07 \\
05 \\
46 \\
02\end{array}$ & $\begin{array}{l}12 \% \\
08 \% \\
77 \% \\
03 \%\end{array}$ \\
\hline 4. & \begin{tabular}{ll}
\multicolumn{2}{l}{ Religion: } \\
a. Hindu \\
b. Muslim \\
c. Christian \\
d. Any other
\end{tabular} & $\begin{array}{l}45 \\
12 \\
03 \\
00\end{array}$ & $\begin{array}{l}75 \% \\
20 \% \\
05 \% \\
00 \%\end{array}$ \\
\hline 5. & $\begin{array}{l}\text { Type of family: } \\
\text { a. Joint family } \\
\text { b. Nuclear family }\end{array}$ & $\begin{array}{l}20 \\
40\end{array}$ & $\begin{array}{l}34 \% \\
66 \%\end{array}$ \\
\hline 6 & $\begin{array}{l}\text { Monthly family income in } \\
\text { rupees: } \\
\text { a. } 5000-7000 \\
\text { b. } 7001-9000 \\
\text { c. } 9001-11000 \\
\text { d. Above } 11000\end{array}$ & $\begin{array}{l}13 \\
19 \\
17 \\
11\end{array}$ & $\begin{array}{l}22 \% \\
32 \% \\
28 \% \\
18 \%\end{array}$ \\
\hline
\end{tabular}




\section{International Journal of Science and Research (IJSR) \\ ISSN (Online): 2319-7064}

Index Copernicus Value (2013): 6.14 | Impact Factor (2015): 6.391

Section II-Assessment of knowledge regarding antenatal care among pregnant women before and after administration of structured teaching programme

Table 2: frequency and percentage distribution in pre-test and post-test level of knowledge

\begin{tabular}{|c|c|c|c|c|}
\hline \multirow{2}{*}{$\begin{array}{l}\text { Level of } \\
\text { Knowledge }\end{array}$} & \multicolumn{2}{|c|}{ Pre-test } & \multicolumn{2}{c|}{ Post test } \\
\cline { 2 - 5 } & Frequency & $\begin{array}{c}\text { Percentage } \\
(\%)\end{array}$ & Frequency & $\begin{array}{c}\text { Percentage } \\
(\%)\end{array}$ \\
\hline Very poor & 00 & 00 & 00 & 00 \\
\hline Poor & 8 & 13.33 & 00 & 00 \\
\hline Average & 49 & 81.66 & 25 & 41.66 \\
\hline Good & 3 & 5 & 30 & 50 \\
\hline Very good & 00 & 00 & 5 & 8.33 \\
\hline Total & 60 & 100.0 & 60 & 100.0 \\
\hline
\end{tabular}

SECTION III: Effectiveness of structured teaching programme on knowledge regarding antenatal care among pregnant women

Table 3: mean, standard deviation, mean difference and ' $t$ ' value of pre- test and post test scores.

\begin{tabular}{|c|c|c|c|c|c|}
\hline \multicolumn{2}{|c|}{ Variables } & Mean & Mean difference & Std. Deviation & t-value \\
\hline \multirow[b]{2}{*}{ Knowledge } & Pre-test & 12.55 & \multirow[b]{2}{*}{3.700} & 1.826 & $9.487 *$ \\
\hline & Post-test & 16.25 & & 2.433 & $\begin{array}{c}\mathrm{Df}=59 \\
\mathrm{P}=3.2342\end{array}$ \\
\hline
\end{tabular}

Section IV- Table-4 Association between pre test knowledge score and selected demographic variables

\begin{tabular}{|c|c|c|c|c|c|c|c|c|c|c|}
\hline \multirow{2}{*}{$\begin{array}{c}\text { Demographic } \\
\text { Variables }\end{array}$} & \multirow{2}{*}{ Category } & \multirow[t]{2}{*}{$\mathrm{N}$} & \multicolumn{3}{|c|}{ Pre value } & 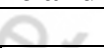 & \multicolumn{2}{|c|}{$\chi^{2}$ value } & \multirow[t]{2}{*}{ Df } & \multirow[t]{2}{*}{ Association } \\
\hline & & & poor & average & good & $\begin{array}{l}\text { Very } \\
\text { good }\end{array}$ & $\begin{array}{l}\text { calculated } \\
\text { value }\end{array}$ & \begin{tabular}{|c|} 
Table \\
value at $\mathrm{p}$ \\
$<0.05$ \\
level \\
\end{tabular} & & \\
\hline \multirow{4}{*}{$\begin{array}{l}\text { 1. Age of } \\
\text { mothers }\end{array}$} & $18-23$ & 10 & 1 & 8 & 1 & 0 & \multirow[t]{4}{*}{8.557} & \multirow[t]{4}{*}{7.82} & \multirow[t]{4}{*}{ Df:3 } & \multirow[t]{4}{*}{$\mathbf{S}$} \\
\hline & $24-28$ & 32 & 4 & 22 & 5 & 1 & & & & \\
\hline & $29-33$ & 12 & 0 & 8 & 3 & 1 & & & & \\
\hline & $34-38$ & 6 & 2 & 2 & 1 & 1 & & & & \\
\hline \multirow{4}{*}{$\begin{array}{l}\text { 2. Educational } \\
\text { status of } \\
\text { mother }\end{array}$} & Primary school & 20 & 2 & 15 & 1 & 2 & \multirow[t]{4}{*}{8.457} & \multirow[t]{4}{*}{7.82} & \multirow[t]{4}{*}{ Df:3 } & \multirow[t]{4}{*}{$\mathbf{S}$} \\
\hline & Middle school & 12 & 2 & 6 & 4 & 0 & & & & \\
\hline & High school & 11 & 1 & 8 & 1 & 1 & & & & \\
\hline & Illiterate & 17 & 2 & 11 & 4 & 0 & & & & \\
\hline \multirow{4}{*}{$\begin{array}{l}\text { 3. Occupation } \\
\text { of mothers }\end{array}$} & Household worker & 7 & 1 & 5 & 1 & 0 & \multirow[t]{4}{*}{13.807} & \multirow[t]{4}{*}{7.82} & \multirow[t]{4}{*}{ Df:3 } & \multirow[t]{4}{*}{$\mathbf{S}$} \\
\hline & Healthcare worker & 5 & 0 & 4 & 1 & 0 & & & & \\
\hline & House wife & 46 & 5 & 31 & 8 & 2 & & & & \\
\hline & Others & 2 & 1 & 0 & 0 & 1 & & & & \\
\hline \multirow[t]{3}{*}{ 4. Religion } & Hindu & 45 & 6 & 29 & 8 & 2 & \multirow[t]{3}{*}{2.083} & \multirow[t]{3}{*}{5.99} & \multirow[t]{3}{*}{ Df:2 } & \multirow[t]{3}{*}{ NS } \\
\hline & Muslim & 12 & 1 & 8 & 2 & 1 & & & & \\
\hline & Christian & 3 & 0 & 3 & 0 & 0 & & & & \\
\hline \multirow{2}{*}{$\begin{array}{l}\text { 5. Type of } \\
\text { family }\end{array}$} & Joint & 20 & 1 & 13 & 4 & 2 & \multirow[t]{2}{*}{2.855} & \multirow[t]{2}{*}{3.84} & \multirow[t]{2}{*}{ Df: 1} & NS \\
\hline & Nuclear & 40 & 6 & 27 & 6 & 1 & & & & \\
\hline 6. Monthly & $5000-7000$ & 13 & 1 & 10 & 1 & 1 & 5.76 & 7.82 & Df:3 & NS \\
\hline family income & $7001-9000$ & 19 & 1 & 13 & 5 & 0 & & & & \\
\hline & 9001-11000 & 17 & 3 & 10 & 3 & 1 & & & & \\
\hline & above 11000 & 11 & 2 & 7 & 1 & 1 & & & & \\
\hline
\end{tabular}

\section{Conclusion}

In present study, assess the level of knowledge on antenatal care among pregnant women of selected rural area. Effectiveness was assessed by analysis of pre-test and posttest level of knowledge score. The data was interpreted by suitable and appropriate statistical method.

\subsection{Recommendations}

In the light of the above findings and personal experience of the investigator the following recommendations are offered:

- The study can be replicated on a larger sample; thereby findings can be generalized for a larger population.
- A similar study can be conducted to assess the knowledge level of women regarding antenatal care.

- Pamphlets or information booklets can be prepared with the guidance of this structured teaching programme and distributed among pregnant women to get awareness about antenatal care.

\section{Acknowledgements}

I express my sincere gratitude to Mr. Ravindra H.N., Principal, Sumandeep Nursing College, for his valuable suggestions and constant encouragement given throughout the period of study. 


\section{International Journal of Science and Research (IJSR) \\ ISSN (Online): 2319-7064}

Index Copernicus Value (2013): 6.14 | Impact Factor (2015): 6.391

I would like to take this opportunity to express my profound gratitude and deep regard to my guide, Ms. Sijo Koshy, HOD of Obstetric and Gynaecological Nursing, for her exemplary guidance, valuable feedback and constant encouragement throughout the duration of research project. Her perceptive criticism kept me working to make this research project in a much better way. Working under her was an extremely knowledgeable experience for me.

I would also like to give my sincere gratitude to my co-guide Ms. Rita Thapa, Associate Professor, Department of Obstetric and Gynaecological Nursing who provided expertise that greatly assisted in the research and successfully completed in every phase of the research project.

\section{References}

[1] Mayer, et al (1998). "Text book for Midwifery" (11 ${ }^{\text {th }}$ edition) London: Bailliese.

[2] Amarnath, et al (2000) "Textbook of obstetric for nurses and midwives" $1{ }^{\text {st }}$ Edition New Delhi, 2000, 2nd edi, Workman publishers.

[3] WHO, "antenatal care." London. Shower medical publishers. 2004. 2nd edi, P no. 66

[4] "The Nursing Journal of India" vol 11 Nov 2008, plos One. 2013; 8(1): 53747. Published online 2013 Jan 15. Doi: 10.1371 /journal. pone.0053747.

[5] Swami N .obstetrics outcome in young primigrevida. Obstetric and gyenecol 2003;21. Http://www.pubmed.com,11/ 304

[6] Amarnath g.b hide,(2000) "Textbook of obstetric for nurses and midwives" $1{ }^{\text {st }}$ Edition New Delhi, Workman publishers.

[7] Mayer (1998). "Text book for Midwifery" (11 $1^{\text {th }}$ edition) London: Bailliesetindall.

[8] DUTTA D.C,(1998) "Text Book of obstetrics and contraception" $6^{\text {th }}$ edition New central book agency, New Delhi

[9] Samuel e Anya, Abba Hydara et al.O opportunity for information and Education about tenatal nutrition. Journal of bio med central, pregnancy and childbirth,2008 march.

[10] Benet VR, Brown LK. Myles.Text book for midwives. $13^{\text {th }}$ ed. 2011. Churchill

\section{Author Profile}

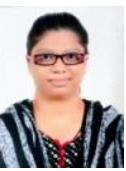

Mrs. Pinal Bhabhor, (M.Sc. Nursing student, Sumandeep Nursing College, Sumandeep Vidyapeeth, Piparia, Vadodara-391760, Gujarat,India

Ms. Sijo Koshy, Associate Professor, Obstetrics \& Gynaecological Nursing, Sumandeep Vidyapeeth-Sumandeep Nursing College, Vadodara, Gujarat, India 